\title{
Cloning and Expression of the Creatinase Gene from Flavobacterium sp. U-188 in Escherichia coli
}

\author{
Yasuji Koyama, Satoshi Kitao, Hideko Yamamoto-Otake, \\ Masaru SUzUKI* and Eiichi NAKANO \\ Research and Development Division, Kikkoman Corporation \\ and ${ }^{*}$ Noda Institute for Scientific Research, \\ Noda 399, Noda-shi, Chiba 278, Japan
}

Received December 20, 1989

\begin{abstract}
The gene coding for creatinase (creatine amidinohydrolase, EC 3.5.3.3) was isolated from Flavobacterium sp. U-188. The primary structure of creatinase deduced from the nucleotide sequence showed a protein (molecular weight, 42,651 ) composed of 378 amino acids. The creatinase gene was over-expressed in Escherichia coli under the control of the lac promoter and the amount of this enzyme was over $20 \%$ of the soluble protein in the cell.
\end{abstract}

Creatinase (creatine amidinohydrolase, EC 3.5.3.3) catalyzes the hydrolysis of creatine to sarcosine and urea. In a previous paper ${ }^{1)}$ we developed an enzymatic method for measurement of creatinine using creatinase in combination with creatininase (creatinine amidohydrolase, EC 3.5.2.10) and sarcosine oxidase (EC 1.5.3.1) from newly isolated bacteria. Flavobacterium sp. U-188 produces a large amount of creatinase when creatinine or creatine is added to the medium as an inducing substrate. However, the use of the expensive inducer is a disadvantage in industrial production.

In this paper we report the cloning and expression of the gene coding for creatinase from Flavobacterium sp. U-188 in Escherichia coli.

\section{Materials and Methods}

Bacterial strains and media. Flavobacterium sp. U-188 and $E$. coli were grown in $\mathrm{LB}$ medium ${ }^{3)}$ at $30^{\circ} \mathrm{C}$ and $37^{\circ} \mathrm{C}$, respectively. E. coli $\mathrm{HB} 11^{4)}$ was used as a cloning host for construction of a gene library and $E$. coli $\mathrm{JM} 109^{5)}$ was used for sequencing and gene expression. For induction of the creatinase gene regulated by the lac promoter, JM109 harboring a recombinant plasmid was grown in LB medium containing $1 \mathrm{~mm}$ IPTG (isopropyl- $\beta$-D-thiogalactoside). Ampicillin and tetracycline were added at the concentration of $100 \mu \mathrm{g} / \mathrm{ml}$ and $10 \mu \mathrm{g} / \mathrm{ml}$, respectively.
Chemicals. Restriction and modification enzymes were purchased from Takara Shuzo Co., Ltd. (Kyoto, Japan) or Boehringer Mannheim GmbH. Peroxidase was purchased from Toyobo Co., Ltd. (Osaka, Japan) and sarcosine oxidase was obtained from Seishin Pharmaceutical Co., Ltd. (Tokyo, Japan). IPTG and 4-aminoantipyrine (4-AA) were from Wako Pure Chemical Industries, Ltd. (Osaka, Japan) and 2,4-dichlorophenolsulfonate $(2,4-$ DCPS) was from Nacalai Tesque Co., Ltd. (Kyoto, Japan). Creatine was purchased from Sigma Chem. Co., Ltd. (St. Louis, U.S.A.). Other chemicals used were of reagent grade.

Preparation of chromosomal DNA and construction of gene library. Chromosomal DNA was prepared from Flavobacterium sp. U-188 basically by the method of Saito and Miura $^{6)}$ except the addition of a 2-methoxyethanol extraction step introduced by $\mathrm{Kirby}^{7}$ before phenol extraction as the DNA could not be digested with restriction enzymes without this step. The chromosomal DNA fragments in sizes of $49 \mathrm{~kb}$ generated by the partial digestion with Sau3AI were collected by agarose gel electrophoresis $^{8}$ and ligated to the dephosphorylated-BamHI cut pBR322. E. coli HBI01 was transformed with the ligated DNA and plated on a $\mathrm{LB}$ agar plate containing $100 \mu \mathrm{g} / \mathrm{ml}$ of ampicillin.

Screening procedure. Each transformant was grown in $5 \mathrm{ml}$ of LB medium containing $100 \mu \mathrm{g} / \mathrm{ml}$ of ampicillin and $1 \%$ creatine at $37^{\circ} \mathrm{C}$ for $24 \mathrm{hr}$. Cultures were centrifuged and cells were resuspended in $1 \mathrm{ml}$ of $10 \mathrm{~mm}$ phosphate buffer ( $\mathrm{pH} 7.7$ ) containing $1 \%$ creatine and $20 \mu \mathrm{l}$ of toluene. After incubation at $37^{\circ} \mathrm{C}$ for $1 \mathrm{hr}, 0.1 \mathrm{ml}$ each of $0.2 \%$ DCPS, $0.07 \% 4-\mathrm{AA}, 70 \mathrm{u} / \mathrm{ml}$ of peroxidase and $40 \mathrm{u} / \mathrm{ml}$ of sarcosine oxidase were added to the mixture. If 
creatinase is produced in a transformant and hydrolyzes creatine to sarcosine, the reaction mixture turns red.

$D N A$ sequencing. Fragments of DNA were subcloned into $\mathrm{pUCl} 18$ or $\mathrm{pUC} 119^{91}$ and their sequences were identified by a modified dideoxy chain termination method ${ }^{10}$ ) using a 7-DEAZA Sequencing Kit (Takara Shuzo Co., Ltd.).

Assay of creatinase acctivity. All cells used for the enzyme assay were grown to early stationary phase, disrupted by ultrasonication, and centrifuged to obtain the crude extract. The activity of creatinase was measured by the amount of urea from creatine by the method of Watt and Chrisp. ${ }^{11}$ The reaction mixture consisting of $0.1 \mathrm{ml}$ of the crude extract, $0.1 \mathrm{ml}$ of $0.3 \mathrm{M}$ potassium phosphate

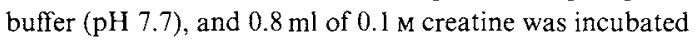
at $37^{\circ} \mathrm{C}$ for $10 \mathrm{~min}$ and the reaction was stopped by adding $2 \mathrm{ml}$ of a color reagent containing $50 \%$ ethanol, $1 \% \mathrm{p}$ dimethylaminobenzaldehyde, and $1 \mathrm{M} \mathrm{HCl}$. The optical density was measured at $435 \mathrm{~nm}$. One unit of creatinase was defined as the amount of enzyme which liberates 1 $\mu$ mol of urea under these conditions.

SDS-polyacrylamide gel electrophoresis and Western blot analysis. For SDS-polyacrylamide gel electrophoresis (SDS-PAGE) $^{12)}$ the cell pellets from $10-\mathrm{ml}$ culture were resuspended in $2 \mathrm{ml}$ of water, disrupted by ultrasonication and centrifuged at $12,000 \mathrm{rpm}$ for $10 \mathrm{~min}$. The supernatant mixed with an equal volume of sample buffer was boiled for $5 \mathrm{~min}$ and $20 \mu \mathrm{l}$ of the mixture was put on a $10 \%$ gel. For measurement of the amount of creatinase produced in a recombinant strain, a gel was stained with Coomasie brilliant blue R-250 and analysed by a densitometer (model 800 fiber optic scanner, Kontes, Vineland, N.J.). Western blots ${ }^{13)}$ were reacted with creatinase-specific antiserum and stained with horseradish-peroxidase-conjugated second antibody using a Bio Rad Immun-Blot Assay Kit (Bio Rad Laboratories, Richmond, CA.). Creatinase specific antiserum prepared from rabbits immunized with the creatinase purified from Flavobacterium sp. U-188 was a gift from Y. Nakajima.

\section{Results}

\section{Cloning of the creatinase gene}

Out of 3200 transformants with ampicillin resistance and tetracycline sensitivity, three strains showed creatinase activity. The recombinant plasmids containing $1.9-\mathrm{kb}, 5.2-\mathrm{kb}$ or 4.3-kb inserts of DNA from Flavobacterium sp. U-188 were designated pKLS501, pKLS511, and pKLS521. The restriction maps of these insert DNA in the recombinant plasmids are shown in Fig. 1. The 1.9-kb fragment

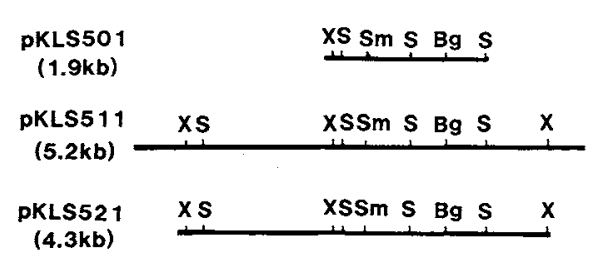

Fig. 1. Restriction Maps of the Recombinant Plasmids Carrying Creatinase Gene.

Only the insert segments from Flavobacterium sp. U-188 are shown. Restriction sites: $\mathrm{Bg}, \mathrm{Bg} / \mathrm{II} ; \mathrm{S}, \mathrm{SalI}$; $\mathrm{Sm}, \mathrm{SmaI}$; $\mathrm{X}$, XhoI.

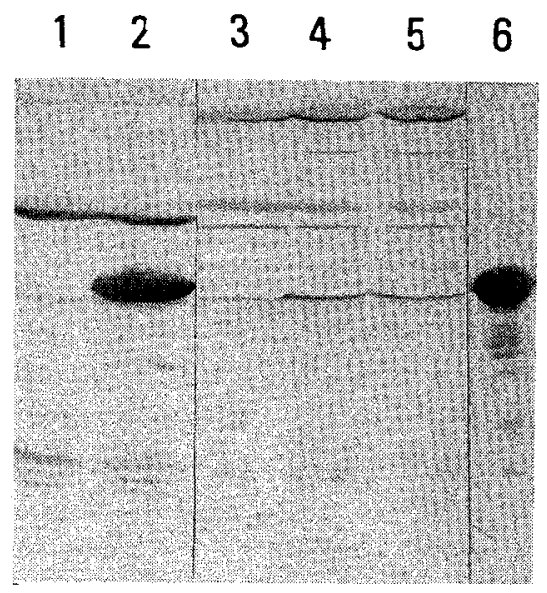

Fig. 2. Western Blotting Analysis of Extracts from Flavobacterium sp. U-188 (lanes 1 and 2), E. coli HB101 (lane 3), HB101 Harboring pKLS501 (lanes 4 and 5) and Creatinase Purified from Flavobacterium sp. U-188 (lane 6).

The samples in lanes 2,3 , and 5 were the extracts of cells grown in the medium containing creatine. The arrow indicates the position of creatinase.

of pKLS501 was common to the other recombinant plasmids.

The creatinase activity of $\mathrm{HB} 101$ harboring pKLS501 was $0.0084 \mathrm{u} / \mathrm{ml}$ culture and Western blot analysis showed that HB101 cells carrying the recombinant plasmid pKLS501 constitutively produced creatinase, while Flavobacterium sp. U-188 did not produce the enzyme at all in the absence of creatine (Fig. 2).

\section{Sequencing of the creatinase gene}

The nucleotide sequence of the $1.9-\mathrm{kb}$ insert of DNA in pKLS501 was identified and found to contain a single open reading frame of 
GATCGGGCGATGGAGGCCAACCTCCAGGAGCCGATCGAGCTGGACGAGCTGGCCGAGCTCATCCAGCTGTCGCGCCCTCACCTCGAGCGGCTGTTTCGC 100 AAATACCTGCGCTGCTCGCCCTCGCGCTACTACATGAGCTCGCCTGCTGCGCGCGCGCGAGCTCTTGCGCCAGACCGAGTTGCCGGTGGTGCAGGTCGCG 200

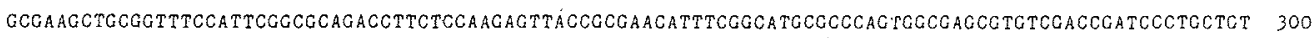
GTCGCGCAGCCGTCCACTGAGCGCCAGCTTCCCGTTGGCCCCCCTCCTCGTAGCCGGCTTTTTTTTGCCCGTTCGTCACCCCCTCTCAGGCGCTGCAGCC 400 GAGTGGCGACGGGCTGCGGGCGTGCGGTGATGGCCTTATGACCGCGCCCGGGCCGTTCGGCAGCCGAGCGAATCTCACCAACTTGAGGTCGGATACGTG 500 CAARAGGCCCCCGCGGGTTCTCTTGCAATGTCTTCAACGCCAGCCACTCCGGTGTCCCAGATCAGTGAATAACAAGAAGGGTTCTCGTCATGCAAATGCC 600 $\underline{\underline{S m a} I}$ MetGinMetPr

CAAAACACTCCGCATCCGCAACGGTGAAAAGGTCAAGTCCACGTTCTCCGCGCAGGAATACGCCAACCGCCATGCCAAGCTGCGCGCGCACCTGCCGGCO oLysThrLeuArgIleArgAsnGlyGluLys ValLys SerThrPheSerAlaGlnGluTyrAlaAsnArgHisAlaLysLeuArgAlaHis LeuAlaAla

GAGAACATCGATGCTGCGGTCTTCACGTCGTACCACAACATCAACTACTACTCCGACTTCCTGTACTGCTCCTTCGCTCGTCCCTACGCCCTCGTCGTCA GIUAsnIleAspALAlaValPheThrSerTyrHisAsnIleAsnTyrTyrSerAspPheLeuTyrCysSerPheGlyArgProTyrAlaLeuValvalT CGCAGGACGACGTGATCACCATCAGCGCCAACATCGACGGTGCCCAGCCGTGGCGCGGCACCGTGGCGACGACAACATCGTCTACACCGACTGGCAGCG hrGInAspAspValI leSerileSerAlaAsnIleAspGlyGlyGInProTrpArgArgThrValGlyThrAspAsnIleValTyrThrAspTrpGlnAr

CGACAACTACTTCGTCGCCATCCAGCAGGCGCTGCCCAGGGCGCGTCGCATCGGTATCGACCACGACCACCTCAACCTGCAGAACCGCGACAAGCTGGCC 1000 gAspAsnTyrPheValAlaIleGInGInAlaLeuProArgAlaArgArgIleGIyIleGIuHisAspHisLeuAsnLeuGInAsnArgAspLys LeuAla

GCCCGCTACGCGGA TGCCGAGCTGGTCGACGTGGCCGCCGCCTGGATGCGCATGGGCATGATCAAGTCGGCTGAAGAGCACGAGATGATCCGCCATGGCG 1100 AlaArgTyrProAspAlaCluLeuValAspValAlaAlaAlaCysMetArgMetargMetIleLysSerAlaGluGIuHisGIuMetIleArgHisGly A

GGCGCGTCGCCGACATCGGTGGCGCGGCCATCGTCGAGGCCCTGCGTGATCAGGTGCGGGAGTACGAAGTGGCGCTGCACGCGACGCAGGCCATGGTGCG 1200 laArgValAlaAspIleGlyGlyAlaAlaIl eValGluAlaLeuArgAspGlnValProGiuTyrGiuValAlaLeuHis slaThrGlnAlaMetValAr .

CGCCATTGCCCACACCTTCGACAACGTCGAGCTGATGGACACCTGGACCTCGTTCCAGTCGGCCATCAACACCGACGGCGCGCACAACCCGGTGACCACC 1300 gAlaIleAlaGluThrPheAspAsnValGiuLeuMetAspThrTapthrTrpheGinSerGlyIleAsnThrAspGlyAlaHisAsnProvalThrThr

CGCAAGGTCAACAAGGGCGACATCCTCACCCTGAACTGCTTCCCGATGATCGCCGGTTACTACACCGCGCTGGAGCGTACCCTGTTCCTCGACCACTCCT 1400 Arg Lys VaIAsnLysGlyAspIleLeuSerLeuAsnCys PheProMetIleAlaGly TyrTyrThrAlaLeuGluArg ThrLeuPheLeuAspHisCysS

CCGACGACCACCTGCGCATGTGGCAGGCCAACOTCGAAGTGCACGAGGCCCGCCTCAAGCTGATCAAACCGGGCA TGCGCTGCAGCGACATCGCCAACGA I500 erAspAspHisLeuArgMetTrpGInAlaAsnVaIGluVaIHisGluAlaGly LeuLysLeuIleLysProGIyMetArgCysSerAspIleAlaLysGl

GCTCAACGAGATCTTCCTCAAGCACGATCTGCTGCAGTACCOCACCTTCGGTTACGGTCACTCCTTCGGCACCCTCACCCACTACTACGCCCGCGACGCG 1600 uLeuAsnCluIlePhe LeuLysHis AspLeuLeuGlnTyrArgThrPheGly TyrGlyHisSerPheG1yThrLeuSerHisTyrTyrGlyArgAspCly

CCTGGAGCTGCGCGAGACATCGACACCGTTCTGGAGCCGGGCATGGTGGTCTCCATGGAGCCGATGATCATGCTCCCCGAAGGTCGTCCGCGCGCCGGT 1700 ProGlyAlaAlaArgClyHisArgHisArg SerGlyAlaGlyHisGlyGly LeuHisGlyAlaAspAspHisAlaAlaArgArgSerSerGlyArgArgT

GGCGTACCGCGAGCACGACATCCTGATCGTCAACGAGAACGGTCCCGACAACATCACCAAGTTCCCGTACGCTCCGGAGAGAAACATCATCCGCAAATAA 1800 rpArgThrAlaSerThrThrSer

CCGCTGCGCCCCGCAGGG TCACGACCTGCGCGGGGCAACTGOCTGCAACACGCAAAACCGAACCTCCCTGCCACACGCCTGGAAGCCCGCTTCCCGTCGA 1900 CTGCGCTTTCACTCCCCGTTGCCGAACACAACAACAAGAGGAACAGGCGATGATC

Fig. 3. The Nucleotide Sequence of the Insert DNA of pKLS501 and the Deduced Amino Acid Sequence of Creatinase.

The arrows indicate inverted repeats. The putative ribosome binding site is underlined.

$1134 \mathrm{bp}$ (Fig. 3). The protein deduced from the nucleotide sequence was composed of 378 amino acids with a molecular weight of 42,651 . The deduced amino acid sequence was consistent with the sequence of 15 amino acids from the amino terminal of creatinase of Flavobacterium sp. U-188 found by a Protein Sequencer (Applied Biosystems Inc. Type 470A) (data not shown).

There was a typical $\rho$-independent terminator, a GC-rich dyad symmetry element followed by a run of $\mathrm{T}$ residues, ${ }^{14)}$ in the region between positions 338 and 366 . As subcloning of the 1.9-kb fragment of pKLS501 downstream of a lac promoter or a trp promoter did not affect the creatinase productivity, this putative terminator was perhaps functional in E. coli (data not shown).

\section{Subcloning and overexpression}

The 864-bp ClaI-SmaI fragment of pKLS 501 was replaced by the 216-bp PvuII-SmaI fragment containing the lac promoter of pUC19 to construct pKLS508 (Fig. 4) in which the creatinase gene was expressed under the control of the lac promoter and operator. The creatinase activity of JM109 harboring pKLS508 was 1.80 units $/ \mathrm{ml}$ culture with $1 \mathrm{~mm}$ IPTG, which is 50 -fold higher than that without IPTG. SDS-PAGE analysis of the crude extract showed that the amount of creatinase produced by JM109 carrying pKLS508 in the presence of IPTG reached about $20 \%$ of the soluble protein in the cell (Fig. 5). 


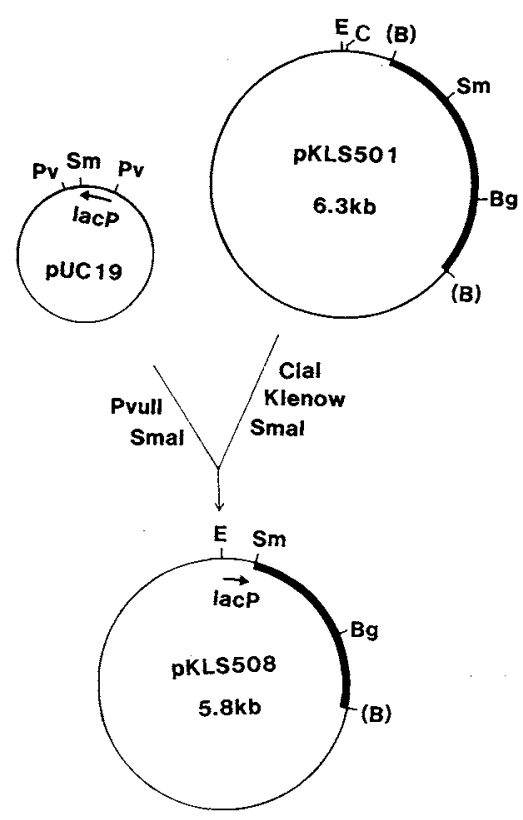

Fig. 4. Construction of pKLS508 for the Overexpression of Creatinase

Abbreviations: lacP, lac promoter; B, BamHI; Bg, $B g l \mathrm{II}$; C, ClaI; E, EcoRI; Pv, PvuII; S, SmaI.

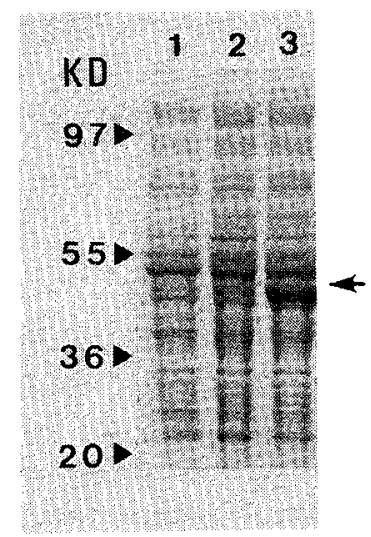

Fig. 5. SDS-PAGE Analysis of Crude Extracts-from Recombinants.

lane 1, HB101 (pKLS501); lane 2, JM109 (pKLS508) not induced; lane 3, JM109 (pKLS508) induced by IPTG. The arrow indicates the position of creatinase.

\section{Discussion}

A large amount of creatinase is required for diagnostic use because of the low affinity of creatinase for creatine $(K m=40 \mathrm{~mm}) .{ }^{2)}$ Furthermore the use of the expensive inducing substrate is a high barrier for the commercial production of the enzyme.

In this paper we resolved these problems by cloning the creatinase gene and constructing an overproducing strain. High productivity of the creatinase by the recombinant strain led to simplification of the purification process and improvement of the quality of the enzyme. Moreover, the creatinase gene was subcloned into the Sleeper bacteriophage vector ${ }^{15,16)}$ and expressed by heat induction without addition of the inducer (data not shown).

The properties of the recombinant creatinase were not appreciably different from those of the Flavobacterium creatinase (data not shown). Therefore, we guess that the creatinase was produced as an active form in $E$. coli JM109 harboring pKLS508.

E. coli HB101 harboring pKLS501 expressed very low activity of creatinase although it was considered to contain the entire creatinase gene. This result suggests that a promoter of Flavobacterium was not functional in $E$. coli. The high production of the pKLS508 clone regulated under a lac promoter may result from the highly conservative sequence of the ribosome binding site and codon usage, minor tRNAs ${ }^{17)}$ of $E$. coli being almost never used.

The molecular weight of the creatinase predicted from the nucleotide sequence is 42,651 and this is consistent with that estimated by SDS-PAGE of the creatinase produced by JM109 carrying pKLS508. Recently, Hoeffken et $a .^{18)}$ identified the primary and crystal structures of the creatinase from Pseudomonas putida, which has properties corresponded very closely to those of the creatinase from Flavobacterium. The amino acid sequence comparison between Flavobacterium creatinase and Pseudomonas creatinase showed about $80 \%$ homology (data not shown).

Acknowledgments. We wish to thank Dr. S. Nasuno for his appropriate advice and Mrs. K. Saitoh for her technical assistance. We also wish to thank Mr. Y. Nakajima for the antiserum. 


\section{References}

1) M. Suzuki and M. Yoshida, Clin. Chim. Acta, 143, 147 (1984).

2) M. Suzuki and N. Saito, Japan Tokkyo Koho, 778395 (Mar. 9, 1977).

3) R. W. Davis, D. Botstein and J. B. Roth, "Advanced Bacterial Genetics," Cold Spring Harbor Laboratory, Cold Spring Harbor, N.Y., 1980, p. 201.

4) H. W. Boyer and D. Roulland-Dussoix, J. Mol. Biol,, 41, 459 (1969).

5) J. Messing, Gene, 33, 103 (1985).

6) H. Saito and K. Miura, Biochim. Biophis. Acta, 72 , 619 (1963).

7) K. S. Kirby, Biochem. J., 64, 405 (1956).

8) R. C. A. Yang, J. Lis and R. Wu, in "Methods in Enzymology," Vol. 68, ed. by R. Wu, Academic Press, New York, 1979, pp. 176-182.

9) J. Vieira and J. Messing, in "Methods in
Enzymology," Vol. 153, ed. by R. Wu and L. Grossman, Academic Press, New York, 1987, pp. $3-11$.

10) S. Mizusawa, S. Nishimura and F. Seera, Nucl. Acids Res., 14, 1319 (1986)

11) G. Watt and J. D. Chrisp, Anal. Chem., 26, 452 (1954)

12) U. K. Laemmli, Nature, 227, 680 (1970).

13) W. H. Burnette, Anal. Biochem., 112, 195 (1981).

14) W. H. Holmes, T. Platt and M. Rosenberg, Cell, 32, 1029 (1983).

15) E. Nakano and T. Masuda, Agric. Biol. Chem., 46, 313 (1982).

16) Y. Koyama and E. Nakano, Agric. Biol. Chem., 54, 1315 (1990).

17) T. Ikemura, J. Mol. Biol., 151, 389 (1981).

18) H. W. Hoeffken, S. H. Knof, P. A. Bartlett, R. Huber, H. Moellering and G. Schumacher, J. Mol. Biol., 204, 417 (1988). 